\author{
ANNA WARDA \\ Uniwersytet Łódzki \\ Wydział Filologiczny \\ Instytut Rusycystyki \\ Zakład Literatury i Kultury Rosyjskiej \\ 90-226 Łódź \\ ul. Pomorska 171/173 \\ anna.warda@uni.lodz.pl
}

\title{
W KRĘGU „CYKLU FELICYJSKIEGO” \\ - ODA POCHWALNA DYMITRA IWANOWICZA \\ CHWOSTOWA PT. POLSKIEJ FELICY
}

\section{EXPLORING THE “FELITSA CYCLE": ON DMITRY KHVOSTOV'S PANEGYRICAL ODE "TO THE POLISH FELITSA"}

W artykule omówiona została oda pochwalna osiemnastowiecznego rosyjskiego poety - Dymitra Iwanowicza Chwostowa pt. Polskiej Felicy. Utwór ten plasuje się wśród innych wierszy tworzących tzw. „cykl Felicyjski”. Pierwszym chronologicznie ogniwem tego cyklu i jednocześnie utworem, który zainicjował kolejne wchodzące w jego skład teksty była oda znakomitego poety rosyjskiego końca XVIII - początku XIX wieku - Gabriela Dierżawina pt. Felica. Utwór Chwostowa odwołuje się do konkretnych wydarzeń historycznych tamtych czasów, ale także do wierszy innych autorów pod względem poetyki, obrazowości, jak też środków wyrazu. Postać carycy Felicy nawiązuje natomiast do jej bajkowego prototypu, którego autorką była sama Katarzyna II, jak również do bohaterki wspomnianej ody Dierżawina Felica.

Słowa kluczowe: cykl, oda, Dymitr Iwanowicz Chwostow, Felica, Gabriel Dierżawin, XVIII-XIX wiek, Katarzyna II.

The article discusses the panegyrical ode "To the Polish Felitsa" by the $18^{\text {th }}$-century Russian poet Dmitry Khvostov, a work belonging to the so-called "Felitsa Cycle". The first element of the cycle, both chronologically and in the sense of having initiated all subsequent compositions, is the ode "Felitsa" by the eminent Russian poet of the turn of the $19^{\text {th }}$ century, Gavrila Derzhavin. Khvostov's panegyric refers to specific historical events of the writer's times, as well as to other authors' poems in terms of poetics, imagery and means of expression. The figure of the empress Felitsa, in turn, echoes both her prototype from Catherine II's fable and the heroine of Derzhavin's abovementioned ode.

Translated from the Polish by Marta Kaźmierczak

Keywords: cycle, ode, Dmitry Khvostov, Felitsa, Gavrila Derzhavin, $18^{\text {th }}$ century, $19^{\text {th }}$ century, Catherine II. 
Wśród ponad trzydziestu utworów poetyckich, które weszły w skład wyodrębnionego przez autorkę niniejszego artykułu „cyklu Felicyjskiego”, nie znalazły się cztery utwory znalezione przez nią już po opublikowaniu monografii poświęconej temu cyklowi. Są to: Matka swych narodów (Die Mutter Ihres Volkes, 1793) P.-A. Fogta, Felica matka narodów (Фелиияа матерь народов, 1793) Piotra Iwanowicza Czeliszczewa, Felica matka swoich poddanych (Фелица матерь подданных своих, 1793) Iwana Iwanowicza Wiena oraz oda zatytułowana Polskiej Felicy (Польской Фелище, 1796) autorstwa Dymitra Iwanowicza Chwostowa. Pierwsze trzy z wymienionych utworów zostały już opisane szczegółowo w artykule, który oczekuje na publikację ${ }^{2}$. Czwarty utwór - wiersz Dymitra Iwanowicza Chwostowa pt. Polskiej Felicy, został odszukany chronologicznie najpóźniej i będzie omówiony w niniejszym artykule. Mamy nadzieję, że szczegółowa, intertekstualna analiza tego utworu przyczyni się do uzupełnienia brakującego ogniwa składającego się na „cykl Felicyjski”. Przypomnijmy, że cykl ten tworzy grupa ponad trzydziestu autonomicznych utworów poetyckich różnych autorów, napisanych w stosunkowo długim przedziale czasowym: od lat osiemdziesiątych XVIII w. do lat trzydziestych XIX stulecia. Wiersz Chwostowa poświęcony „polskiej Felicy” jako napisany w 1796 roku plasuje się w drugim wyodrębnionym przez autorkę etapie tego cyklu, czyli w okresie pomiędzy 1790 i 1803 rokiem ${ }^{3}$. Wyznacznikiem spójności tekstów tworzących „,cykl Felicyjski” ${ }^{4}$ są obecne w ich tytułach i/bądź treści odwołania do słynnej satyry-ody Gabriela Dierżawina pt. Felica (Фелица, 1782), która stanowi zresztą pierwsze i jednocześnie najwcześniejsze pod względem chronologicznym jego ogniwo. Osiem utworów cyklu jest autorstwa samego G. Dierżawina, pozostałe zaś napisane zostały przez znanych, anonimowych, drugo-, a nawet trzeciorzędnych poetów, którzy aktywnie uczestniczyli w życiu literackim swojej epoki.

\footnotetext{
${ }^{1}$ A. Warda, „Cykl Felicyjski” w poezji rosyjskiej końca XVIII - początku XIX w., Łódź: Wydawnictwo PRIMUM VERBUM 2013.

${ }^{2}$ Tekst artykułu został wygłoszony w formie referatu na konferencji w Sankt Petersburgu w grudniu 2014 r. nt. Классическая традииия и неклассическая литература в истории русской культуры zorganizowanej przez: Petersburski Uniwersytet Państwowy, Rosyjską Akademię Nauk, Uniwersytet E. M. Arndta w Greifswaldzie (Niemcy) i Uniwersytet F. Schillera w Jenie (Niemcy). Artykuł jest już po recenzji i oczekuje na druk.

${ }^{3}$ A. Warda, „Cykl Felicyjski” w poezji rosyjskiej..., s. 99-150.

${ }^{4}$ Jest tu mowa o cyklu czytelniczym (wtórnym), nazwanym tak przez M. Darwina, w przeciwieństwie do cyklu autorskiego (pierwotnego), który został wyodrębniony przez odbiorcę (czytelnika, redaktora, wydawcę, krytyka, badacza) na podstawie wybranej przez niego grupy utworów jednego bądź wielu autorów. Jest to cykl konwencjonalny, wyodrębniony na podstawie istniejących związków między wchodzącymi w jego skład utworami. Powiązania te mogą przebiegać na płaszczyźnie strukturalnej, semantycznej lub pragmatycznej, przy czym podobnie jak w przypadku cyklu autorskiego, tworzące go utwory mogą być napisane w tym samym lub innym przedziale czasowym. Istotne, że każdy z utworów tworzących cykl może jednocześnie funkcjonować poza cyklem, tracąc wówczas część swego kontekstualnego znaczenia, wynikającego z wcześniejszej przynależności do cyklu (por.: М. Н. Дарвин, Проблема циикла в изучении лирики, Кемерово: Изд-во Кемер. гос. ун-та 1983, s. 11).
} 
Autor utworu poświęconego „polskiej Felicy” - Dymitr Iwanowicz Chwostow (1757-1835) był jednym z bardziej płodnych poetów końca XVIII - pierwszych dziesięcioleci XIX wieku5 ${ }^{5}$ Zaczął tworzyć w wieku 18 lat i czynił to nieprzerwanie przez następnych sześćdziesiąt lat swego życia, w czasie których napisał setki utworów: wierszy, komedii, dramatów, ód, listów, elegii, satyr, stanc, bajek, epigramatów, inskrypcji, a także dokonał wielu tłumaczeń ${ }^{6}$.

Przez wszystkie lata swej twórczości Chwostow był wierny ideom klasycyzmu i nawet w dobie rozkwitu sentymentalizmu i romantyzmu tworzył swe utwory w niemodnym, klasycystycznym stylu. W rezultacie tego już na początku XIX wieku stał się on obiektem drwin ze strony innych pisarzy (m. in. A. Puszkina, W. Żukowskiego, P. Wiaziemskiego, N. Jazykowa, K. Batiuszkowa, J. Baratynskiego, A. Delwiga) i do końca swego życia pozostał symbolem grafomaństwa ${ }^{7}$. Fala krytyki i drwin, z którą spotkał się Chwostow była spowodowana również tym, że miał on potrzebę ciągłego tworzenia i wydawania swych utworów (na własny koszt), które następnie intensywnie rozpowszechniał wysyłając je masowo do znajomych, osób z wyższych sfer, a także różnych instytucji. Co ciekawe, na stronie tytułowej każdego z siedmiu tomów pełnego wydania swych utworów poetyckich zamieścił motto: „За труд не требую и не нуждаюсь славы”.

Należy przy tym zaznaczyć, że do końca XVIII wieku poziom artystyczny utworów Chwostowa nie odbiegał od poziomu innych twórców i dopiero w kolejnym stuleciu, na tle nowych kierunków literackich „klasycystyczna”, archaiczna pod względem formy i języka, często publikowana i rozprowadzana $\mathrm{w}$ dość nachalny sposób twórczość literacka Chwostowa zaczęła być postrzegana i oceniana w pejoratywny sposób.

Wymieniony w tytule niniejszego artykułu wiersz Dymitra Chwostowa zatytułowany Polskiej Felicy był napisany przez niego w 1796 r., a więc jeszcze w czasach, kiedy pisarz nie był obiektem drwin i krytyki środowiska literackiego. Autor umieścił go w dwóch nakładach pełnego wydania swych utworów poetyckich z 1827 i 1830 roku. Warto przy tym zauważyć, że tytuł utworu w drugim wydaniu dzieł pisarza z 1830 roku nosi nieco zmieniony, rozszerzony tytuł - Poświęcony polskiej Felicy (Польской посвященный Фелище). W obu przypadkach jest też podtytuł: W domи Naryszkina (B доме

${ }^{5}$ М. Амелин, Граф Хвостов: писатель и персонаж, Москва: „Совпадение” 1997, [źródło internetowe] http//az.lib.ru/h/hwostow_d_i/text_0060shtml [02.06.2017].

${ }^{6}$ Najważniejsze wydania dzieł D. I. Chwostowa, wydane zresztą na jego własny koszt to: Избранные притчи из лучших сочинителей российскими стихами, Санкт-Петербург 1802; Лирические творения графа Хвостова, Санкт-Петербург 1810; Послания в стихах графа Дмитрия Хвостова, Санкт-Петербург 1814; Полное собрание стихотворений графа Хвостова, чч. 1-4, Санкт-Петербург 1817-1818; то же, изд. 2-е, чч. 1-5, Санкт-Петербург 1821-1827; то же, изд. 3-е, чч. 1-8, Санкт-Петербург 1818-1834.

${ }^{7}$ Por. nр.: М. Амелин, Граф Хвостов: писатель и персонаж...; A. Warda, О литературных взаимоотношениях Д. И. Хвостова и Г. Р. Державина, „Acta Universitatis Lodziensis. Folia Litteraria Rossica” 2015: Tradycja i inwencja w literaturach słowiańskich. Zeszyt Specjalny, pod red. A. Wardy, Łódź 2015, s. 199-216. 
Нарышкина), wskazujący najprawdopodobniej na miejsce, w którym został po raz pierwszy wygłoszony. W wydaniu z 1830 roku jest też podany rok jego powstania - 1796 .

Utwór Chwostowa jest przykładem typowej dla doby klasycyzmu ody panegirycznej, okolicznościowej, napisanej na cześć znakomitej osoby lub poświęconej uświetnieniu ważnego wydarzenia (w tym przypadku pochwała adresata ma miejsce $\mathrm{z}$ okazji jego osiągnięć) i utrzymanej w tonie pochlebstwa lub przesadnego zachwytu ${ }^{8}$. Warto przy tym zauważyć, że w okresie zmierzchu klasycyzmu w tytułach utworów coraz rzadziej stosowano nazwę gatunkową „oda”, zachowując jednocześnie w samym utworze topikę typową dla tego gatunku. Taki przypadek ma właśnie miejsce w wierszu Chwostowa, w którego tytule autor akcentuje przede wszystkim obiekt będący przedmiotem pochwał w samym utworze, a nie jego formę genologiczną.

W omawianej odzie okolicznościowej Chwostowa jej adresatem jest Felica - tytułowa bohaterka ody-satyry Gabriela Dierżawina (1782) i jednocześnie drugoplanowa postać z bajki carycy Katarzyny II napisanej dla wnuka Aleksandra I pt. Bajka o carewiczu Chlorze (Сказка о царевиче Хлоре, 1781). Bajkowa Felica jest córką kirgiz-kajsackiego chana, który porwał carewicza Chlora, by przekonać się o jego niezwykłej bystrości umyśle. $\mathrm{W}$ tym celu dał mu zadanie znalezienia $\mathrm{w}$ ciągu trzech dni róży bez kolców, będącej symbolem cnoty. Felica - osoba o wesołym usposobieniu, miła, uprzejma, dowcipna, oferuje carewiczowi pomoc dając mu przed wyprawą rady, które mają mu się przydać w trudnych poszukiwaniach róży bez kolców. Dla bezpieczeństwa carewicza wysyła z nim swego syna o znaczącym imieniu Rozsądek, który ma go wspierać w poszukiwaniach.

W odzie G. Dierżawina pt. Felica caryca Katarzyna II po raz pierwszy została nazwana imieniem jej własnej bajkowej bohaterki - Felicy. Akceptacja tego utworu przez władczynię, potwierdzona kosztownym prezentem dla Dierżawina (wysadzaną brylantami złotą tabakierką z pięciuset czerwońcami), jak również żywa reakcja ówczesnego środowiska literackiego na tę właśnie odę spowodowały, że caryca nazywana jest $\mathrm{w}$ wielu utworach literackich końca XVIII - pierwszych dziesięcioleci XIX wieku tym właśnie imieniem.

Epitet ,polska” poprzedzający w tytule utworu Chwostowa imię Felicy, ma z kolei bezpośredni związek z okolicznościami, które stały się powodem napisania wiersza poświęconego władczyni Rosji, a mianowicie z trzecim rozbiorem Polski i wszelkimi pozytywnymi konsekwencjami, jakie wiązały się z nim dla narodu rosyjskiego ${ }^{9}$. Władczyni Rosji - sprawczyni tej korzystnej dla

${ }^{8}$ Por. np.: T. Kostkiewiczowa, Oda w poezji polskiej. Dzieje gatunku, Wrocław: Leopoldinum 1996, s. 184-185.

${ }^{9}$ Jak wiadomo, do trzeciego rozbioru doszło w roku 1795 po upadku powstania kościuszkowskiego, w którym Polacy próbowali przeciwstawić się rozbiorom z 1772 i 1793 roku. W rezultacie trzeci rozbiór Polski doprowadził do likwidacji Rzeczypospolitej i wymazania państwa polskiego z mapy Europy. Po długich rokowaniach państwa zaborcze 24 października 1795 r. uzgodniły, jak ma przebiegać podział polskich ziem. W konsekwencji Imperium Rosyjskie znalazło się w centrum Europy zajmując ogromne tereny dawnej Rzeczypospolitej. Do 
Rosji sytuacji stała się, kolejny raz, obiektem pochwał i uwielbienia ze strony ludzi pióra, którzy w imieniu całego narodu składali jej hołd w postaci panegirycznych utworów opiewających jej sukces. Spośród innych utworów tworzących „cykl Felicyjski” jedynie jeden z nich autorstwa Wasyla Kapnista pt. Odpowiedź Rafaela piewcy Felicy (Ответ Рафаэля певиу Фелицы, 1790) bardzo lakonicznie nawiązuje do tych wydarzeń i osadzenia na polskim tronie faworyta Katarzyny II - Stanisława Poniatowskiego oraz do przyłączenia do Rosji ziem zachodniej Ukrainy i Białorusi, należących wcześniej do Polski ${ }^{10}$.

Panegiryk Chwostowa poświęcony ,polskim” sukcesom Katarzyny II składa się z pięciu sześciowersowych zwrotek z parzystym rymem w dwóch pierwszych wersach i okalającym w czterech następnych. Podmiot mówiący plasując siebie w sytuacji podrzędności, a nawet zależności wobec adresata - carycy Felicy, zachowuje należny dystans wobec przedmiotu laudacji i jakby ponad nim zwraca się do szerszego audytorium odbiorców - Rosjan. Wobec nich przyjmuje on postawę wyższości i arbitralnie formułuje swe racje, które wyraża $\mathrm{w}$ postaci zdań postulatywno-apelatywnych. Odbiorca utworu jest więc świadkiem monologu podmiotu mówiącego, który rozwija się w ciągłym napięciu między imiennym adresatem a przesłaniami zwróconymi do zbiorowości - Rosjan. Znajduje to wyraz w przemiennym stosowaniu przez podmiot liryczny form gramatycznych (вы, мы, ты), za pośrednictwem których zwraca się on do swoich rodaków - Rosjan z pozycji nadrzędnej, przemawia jako jeden z nich lub też kieruje wypowiedź bezpośrednio do tytułowej adresatki. W przypadku relacji nadawczo-odbiorczej, kiedy podmiot mówiący przemawia jako jeden z Rosjan i stosuje formę zaimka osobowego „my”, utożsamia się on wówczas ze swymi rodakami, ale jednocześnie jego głos szybko wyodrębnia się z owej zbiorowości i przyjmuje pozycję osoby przemawiającej do nich i przekonującej ich o konieczności realizacji pewnych zadań. W tym przypadku jest to swoisty zabieg perswazyjny, który ma przekonać adresatów jego wypowiedzi do tego, że kierują nim te same racje i że sam jest jednym z nich.

Oda rozpoczyna się apostrofą pochodzącą od podmiotu lirycznego skierowaną do Rosjan, w której nawołuje ich z dużym emocjonalnym zaangażowaniem do głośnego śpiewu i radowania się w tym błogim dniu i czasie. Nie wspomina jednak, co to za szczególny dzień i okoliczność, które stały się powodem do świętowania i wyrażania radości. Więcej informacji na ten temat uzyskujemy z dwóch kolejnych wersów. Rozpoczyna je anafora o charakterze imperatywnym: „Славьте” adresowana przez podmiot liryczny do rodaków. Następujące po niej słowa ujawniają odbiorcy kogo i za co mają sławić w tym szczególnym dniu Rosjanie. Tak więc dowiadujemy się, że osobą tą jest mądra Caryca. Przypomnijmy, że epitet „mądra” znajdujący się

\footnotetext{
Rosji włączono bowiem, w wyniku trzech rozbiorów, obszar liczący około 460 tys. $\mathrm{km}^{2}$ zamieszkany przez 6,5 mln ludności. 25 listopada tegoż roku, w dniu urodzin Katarzyny II odbyła się w Grodnie abdykacja polskiego króla Stanisława Augusta Poniatowskiego.

${ }^{10}$ A. Warda, „Cykl Felicyjski” w poezji rosyjskiej..., s. 114.
} 
przed opisywanym obiektem (jego imieniem, stanowiskiem lub pełnioną funkcją) był w epoce Oświecenia nie bez znaczenia, a tym bardziej w przypadku osoby Katarzyny II. Jak wiadomo, była ona podziwiana przez zachodnich filozofów i uznawana za ucieleśnienie mądrości na tronie $(\mathrm{m}$. in. przez Woltera, Diderota). Nosiła zresztą przydomek „Semiramida ${ }^{11}$ Północy”, nadany jej przez Woltera, z którym prowadziła wieloletnią korespondencję. W Europie szeroko znane było zamiłowanie Katarzyny II do wiedzy i jej działalność oświecicielska w Rosji (m. in. powoływanie szkół ludowych dla najbiedniejszych, twórczość literacka, miłość do dzieł sztuki).

W kolejnym wersie podmiot liryczny ujawnia inną cechę carycy - szczodrość, wykorzystując do tego metonimię „щедрая рука”. Ten właśnie atrybut carycy jest dla jej poddanych, jak oznajmia w wierszu podmiot mówiący, ostoją szczęśliwości i za to właśnie powinni ją wysławiać.

Sytuacja liryczna w następnej zwrotce ody odzwierciedla relacje między podmiotem mówiącym, stosującym tym razem formę zaimka osobowego „my” i przez to utożsamiającym się z określoną zbiorowością (Rosjanami) a wirtualnym odbiorcą utworu. I tak, podmiot mówiący przypomina odbiorcy o wcześniejszych zwycięstwach carycy i walkach, które rozgrywały się na południowych terytoriach. Przypomnijmy, że w latach 1787-1792 miała miejsce wojna Rosji z Turcją, której bezpośrednią przyczyną była wcześniejsza aneksja Chanatu Krymskiego w 1783 r., przekształconego w gubernię taurydzką. Zwycięska dla Rosji wojna z Turcją zakończyła się przyłączeniem do Rosji Krymu i Noworosji. Powiększenie terytorium Rosji od strony południowej, które miało miejsce za sprawą Katarzyny II, przyczyniło się, jak wspomina podmiot liryczny, do tego, że zwycięstwa carycy były opiewane przez cały naród. Przykładem może być, chociażby, wiersz wybitnego rosyjskiego poety - Gabriela Dierżawina pt. Niech rozbrzmiewa pieśń zwycięstwa (Гром победы, раздавайся!, 1791), napisany przez niego na cześć Imperium Rosyjskiego i zwycięstwa carycy Katarzyny II w wojnie rosyjsko-tureckiej oraz zdobycia Krymu, Kaukazu, ujścia Dunaju, a także tureckiej twierdzy Izmaił. Utwór jest również pochwałą rządów Katarzyny II, jej reform wewnętrznych oraz inwestycji państwowych. Muzykę do niego w rytmie poloneza napisał polski kompozytor Józef Kozłowski, znany w Rosji jako Osip Antonowicz Kozłowski. Pieśń ta stała się zresztą nieoficjalnym hymnem Imperium Rosyjskiego od 1791 do 1816 roku$^{12}$. Hymn Dierżawina wspominamy tu

${ }^{11}$ Semiramida - córka syryjskiej bogini Derceto, legendarna królowa babilońska. Rządziła przewyższając rozumem wszystkich współczesnych jej władców, założyła wiele miast, miała liczne przygody miłosne. Po śmierci zmieniła się w gołębicę i uleciała do nieba. Por.: W. Kopaliński, Stownik mitów i tradycji kultury, Kraków 1991, s. 1052-1053.

12 Pierwszy raz hymn został wykonany w Pałacu Taurydzkim w Sankt Petersburgu 28 kwietnia (9 maja) 1791 r. na uroczystości zorganizowanej z okazji zdobycia tureckiej twierdzy Izmaił pod dowództwem A. W. Suworowa. Głównym gościem uroczystości była caryca Katarzyna II. Podczas jej pojawienia się na uroczystości trzystu chórzystów i muzykantów orkiestry symfonicznej oraz kapeli rogowej wykonywali uroczysty polonez Niech rozbrzmiewa pieśn zwycięstwa. 
nieprzypadkowo, ponieważ w odzie Chwostowa zauważalne są wyraźne inspiracje tym utworem. Oba wiersze to panegiryki na cześć Katarzyny II, napisane z okazji zwycięstwa Imperium Rosyjskiego i zdobyczy terytorialnych. Pojawiają się w nich te same lub blisko brzmiące słowa, wyrażenia, anafory (np. w utworze Dierżawina: гром, слава, славься, храбрость, премудрая, царица, десница, зри; w odzie Chwostowa: громко, славьте, храбрые, премудрая, царица, десница, зри). Porównajmy dla przykładu dwa fragmenty utworów obu autorów:

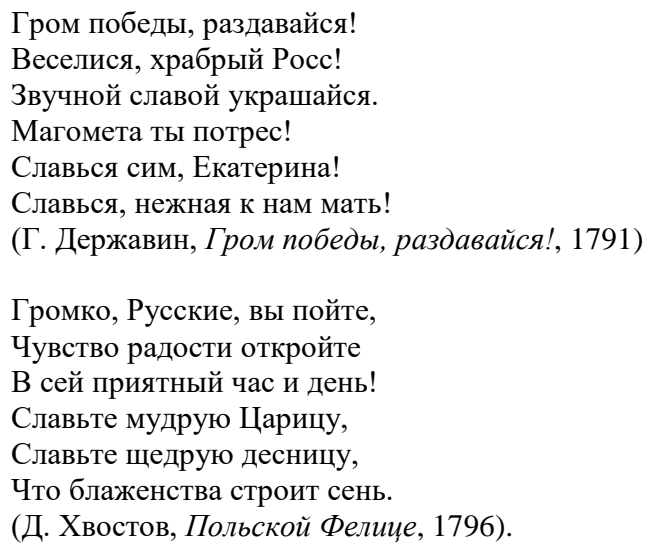

W dalszej części zwrotki poświęconej zwycięstwom Rosji na południowych terytoriach pojawia się, oczywiście w kontekście postaci carycy, motyw wieńca laurowego. Jak wiadomo, wieniec laurowy znany jeszcze z czasów starożytnych był symbolem zwycięstwa i nagrodą w walce, ozdabiano nim głowy zwycięzców. Z czasem wieniec ten stał się również symbolem wybitnych osiągnięć w różnych dziedzinach życia. Pojawienie się go we fragmencie tekstu mówiącego o tym, że zwycięstwa były odnoszone za rządów carycy, nie jest oczywiście przypadkowe i jawi się jako uhonorowanie zasług władczyni w dziedzinie militarnej.

Podmiot liryczny utożsamiając się ze swymi rodakami z dumą mówi, że są oni odważni i stosując metaforę stwierdza, że w razie potrzeby gotowi są nawet oddać swe życie:

Россы храбрые готовы

Кровь свою пролить рекой ${ }^{13}$.

W następnej zwrotce podmiot liryczny zwraca się do carycy stosując formę imperatywną czasownika „зреть” - „зри”, która zostaje powtórzona jako anafora $\mathrm{w}$ następnym wersie $\mathrm{w}$ celu podkreślenia, nadania większego

13 Д. Хвостов, Польской, посвященный Фелице, в доме Нарышкина 1796 года, [w:] tegoż, Полное собрание стихотворений графа Хвостова, ч. 5, Санкт-Петербург 1830, s. 124. 
znaczenia wypowiedzianemu słowu. W taki sam sposób zaczyna się zresztą kolejna zwrotka ody, z tym, że adresatka apelu ma za każdym razem, zgodnie z zaleceniem podmiotu lirycznego, spojrzeć na inne obiekty: radosne twarze wokół siebie, wdzięczne serca, miliony poddanych, dane narodowi nowe przepisy prawne ${ }^{14}$. Zwróćmy przy tym uwagę na występujące $\mathrm{w}$ wymienionych dwóch zwrotkach ody Chwostowa słownictwo związane $\mathrm{z}$ oczami i widzeniem, które było często stosowane w poezji rosyjskiej XVIII wieku ${ }^{15}$. Jak zauważa M. Lewitt, słowa z tej grupy leksykalnej często pojawiały się w poezji epoki klasycyzmu zwłaszcza wtedy, gdy podmiot liryczny zamierzał wyrazić swój zachwyt nad czymś i jednocześnie podzielić się swymi emocjami z rozmówcą/odbiorcą, którego przywoływał za pomocą wizualnego imperatywu „patrz” („зри”), by ten spojrzał, zobaczył, zatrzymał wzrok, uwagę na obiekcie jego zachwytu ${ }^{16}$. Zarówno w przypadku ód panegirycznych, chwalebnych epoki klasycyzmu, jak również w przypadku omawianego utworu Chwostowa, elementem wspólnym w apelach o charakterze wizualnym, jest wyrażenie zwycięskiego zachwytu. Jest to zresztą również podkreślone przez powtórzenia tego apelu, a także znaki wykrzyknikowe, które potwierdzają imperatywny charakter tego rodzaju wypowiedzi. Są one przy tym bardzo emocjonalne, a ich zadaniem było wpłynięcie nie tylko na bezpośredniego adresata ody, ale także jej wirtualnego odbiorcę. Porównajmy dla przykładu dwie zwrotki ody Chwostowa, w których występują wizualne imperatywy:

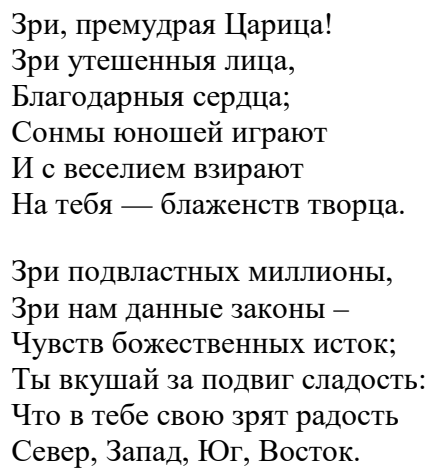

Apel do carycy o to, by spojrzała na swych radosnych poddanych i razem z nimi weseliła się jest równoznaczny z wezwaniem jej samej i wirtualnych odbiorców do zachwytu nad wielkością Rosji - jej potęgą terytorialną,

${ }^{14}$ W 1766 roku Katarzyna II powołała komisję prawodawstwa, która miała opracować kodeks praw, jednak ze względu na wojny rosyjsko-tureckie sprawa ta została odsunięta na dalszy plan. W 1785 roku caryca wydała dwie Gramoty szlacheckie, ustanawiające prawa i przywileje dla szlachty. W tym samym roku wydała również Gramotę miejska, oficjalnie ustanawiając stan mieszczański i kupiecki z własnym samorządem miejskim.

${ }^{15}$ M. Левитт, Визуальная доминанта в России XVIII века, tł. z ang. А. Глебовская, Москва: Новое литературное обозрение 2015, s. 59-68.

${ }^{16}$ Tamże, s. 78. 
a także samą władczynią, dzięki której są odnoszone sukcesy i która przyczynia się do wzrostu potęgi i sławy kraju.

Podmiot liryczny zauważa przy tym, że sukcesy carycy przyniosły jej poparcie wśród młodych ludzi, którzy nie tylko bawią się i radują, ale widzą też osobę, która przyczyniła się do ich szczęścia. Samo określenie władczyni w kontekście tej właśnie sytuacji: „блаженств творец”, sakralizuje jej postać, co zresztą było często stosowane przez rosyjskich poetów opisujących władców Rosji i ich zasługi ${ }^{17}$. Sakralizacja postaci carycy ma też miejsce nieco dalej, kiedy podmiot liryczny mówiąc o jej zasługach stwierdza, że są one źródłem boskich uczuć („Чувств божественных исток”).

W odzie Chwostowa ma też miejsce idealizacja obrazu Rosji czasów Katarzyny. Podmiot liryczny stosując metonimię mówi bowiem, że wszystkie cztery strony podwładnego jej Imperium: północ, zachód, południe i wschód, a ściślej ich mieszkańcy, radują się i są szczęśliwi. Biorąc pod uwagę to, że ludność wielkiego Imperium Rosyjskiego stanowili w niemałej liczbie mieszkańcy ziem przyłączonych do Rosji w rezultacie prowadzonych bojów lub działań politycznych, przedstawiony stan rzeczy był w odzie mocno wyidealizowany i wyolbrzymiony.

Zakończenie ody Chwostowa wyraźnie nawiązuje do jej początku, z którym tworzy swego rodzaju ramę. Obie zwrotki - pierwsza i ostatnia rozpoczynają się słowem „громко”, przy czym w ostatniej zwrotce słowo to jest dodatkowo powtórzone dla nasilenia efektu. Ma też tu miejsce bardziej szczegółowa informacja na temat śpiewu, do którego zachęcał w pierwszej zwrotce podmiot liryczny. Mianowicie dowiadujemy się, że ma być to śpiew wielogłosowy, co wskazywałoby na to, że carycę mają chwalić rzesze jej poddanych, wywodzących się z różnych stanów i będących różnej narodowości.

W odróżnieniu jednak od zwrotki pierwszej, w której, jak pamiętamy, podmiot liryczny, stojąc z boku, nawoływał Rosjan, by głośno śpiewali w tym uroczystym dniu, w zwrotce ostatniej podmiot liryczny wykorzystując formę zaimka osobowego „my”, wyraźnie utożsamia się ze zbiorowością, do której wcześniej przemawiał i z którą dzielił go pewien dystans.

Nawiązanie do zwrotki rozpoczynającej odę ma też miejsce nieco dalej, kiedy podmiot liryczny mówi o widowisku, które było zorganizowane w domu Lwa Aleksandrowicza Naryszkina ${ }^{18}$ (1733-1799) z okazji dokonanego przez Katarzynę II wraz z sojusznikami trzeciego rozbioru Polski. Naryszkin - gospodarz widowiska był początkowo faworytem Piotra III. Po wstąpieniu na tron Katarzyny II został aresztowany jako zwolennik Piotra, ale wkrótce trafił na dwór carycy i całe swoje dalsze życie spędził w otoczeniu władczyni,

${ }^{17}$ A. Warda, Obraz władcy w świetle rosyjskich osiemnastowiecznych dedykacji, [w:] Panegiryk jako element życia literackiego doby staropolskiej $i$ oświeceniowej, pod red. M. Sulejewicz-Nowickiej i Z. Gruszki, Łódź: Wydawnictwo Uniwersytetu Łódzkiego 2013, s. 229-237.

${ }_{18}$ Русский биографический словарь, red. А. А. Половцов, Санкт-Петербург: Издано Императорским Русским Историческим Обществом 1914, t. 11, s. 92-93, [źródło internetowe] http://www.hrono.ru/biograf/bio_n/naryshkin_la.html [03.06.2017]. 
towarzysząc jej w wyprawach po kraju i uczestnicząc w życiu dworskim. Naryszkin odznaczał się przy tym niezwykłą gościnnością, bardzo często organizował bale, maskarady i pikniki. Jedną z takich imprez była, niewątpliwie ta, którą opisał Chwostow w odzie poświęconej „polskiej” Felicy.

Nieco więcej informacji na temat imprezy zorganizowanej w posiadłości Naryszkina, a ściślej mówiąc zgromadzonych na niej honorowych gości, znajdujemy właśnie w ostatniej zwrotce ody. Nie padają tu jednak żadne nazwiska obecnych tam osób, tylko epitety, które ich charakteryzują i które świadczą o ich randze i roli społecznej: odważni, sławni. Podmiot liryczny porównuje ich przy tym do szwedzkiej dynastii Wazów, której członkowie rozszerzyli swe panowanie również na Polskę, a także do osoby Karola Wielkiego, którego Imperium w szczytowym okresie rozwoju obejmowało terytorium wielu współczesnych państw europejskich. Biorąc pod uwagę te właśnie cechy, można się domyślać, że dostojni goście, o których wspomina podmiot liryczny, to sama caryca Katarzyna i dowódcy, dzięki którym Rosja odniosła sukcesy militarne. Na uroczystości są też obecni dwaj specjalni goście: sława $\mathrm{i}$ miłość. Występujące tu $\mathrm{w}$ sytuacji partnerskiej $\mathrm{z}$ opiewaną w odzie carycą spersonifikowane pojęcia oddają charakter atmosfery, jaka panowała na przyjęciu.

Podsumowując możemy stwierdzić, że oda Chwostowa, która wpisuje się w krąg utworów „cyklu Felicyjskiego” była typowym panegirykiem, jakie powstawały na cześć carycy Katarzyny II, odwołującym się do konkretnych wydarzeń historycznych, postaci, ale również do innych utworów swych czasów, zarówno pod względem poetyki, obrazowości, jak też podobnych środków wyrazu. „Polska Felica” pokazana w odzie Chwostowa to przede wszystkim władczyni imperium, wyróżniająca się przede wszystkim mądrością, opiekuńczością wobec swych poddanych oraz odniesionymi sukcesami militarnymi i terytorialnymi. Jej ,polskość” nie przejawia się jednak w tym, że właśnie ten naród jest przez nią traktowany w sposób szczególny, lecz raczej w kontekście jego podległości wobec wielkiej władczyni. Przedstawione przez Chwostowa cechy adresatki jego ody - Katarzyny II jak najbardziej nawiązywały do bajkowego prototypu postaci Felicy, ale także do bohaterki ody Dierżawina Felica.

\section{References}

Amelin, Maksim. Graf Khvostov: pisatel i personazh. Moskva: Sovpadenie, 1997. http//az.lib.ru/h/hwostow_d_i/text_0060shtml

Darvin, Mikhail N. Problema tsikla v izuchenii liriki. Kemerovo: Izdatelstvo Kemerovskogo gosudarstvennogo universiteta, 1983: 11.

Khvostov, Dmitry I. Izbrannye pritchi iz luchshikh sochiniteley rossiyskimi stikhami. Sankt-Peterburg, 1802.

Khvostov, Dmitry I. Liricheskiye tvorenia grafa Khvostova. Sankt-Peterburg, 1810.

Khvostov, Dmitry I. Poslaniya v stikhakh grafa Dmitrya Khvostova. Sankt-Peterburg, 1814. 
Khvostov, Dmitry I. Polnoe sobranie stikhotvoreniy grafa Khvostova. Vol. 1-4, Sankt-Peterburg, 1817-1818.

Khvostov, Dmitry I. Polnoe sobranie stikhotvoreniy grafa Khvostova. Izd. 2-e. Vol. 1-5, Sankt-Peterburg, 1821-1827.

Khvostov, Dmitry I. Polnoe sobranie stikhotvoreniy grafa Khvostova. Izd. 3-e. Vol. 1-8, Sankt-Peterburg, 1818-1834.

Kopaliński, Władysław. Słownik mitów i tradycji kultury. Kraków: Państwowy Instytut Wydawniczy, 1991: 1052-1053.

Kostkiewiczowa, Teresa. Oda w poezji polskiej. Dzieje gatunku. Wrocław: Wydawnictwo Leopoldinum, 1996: 184-185.

Levitt, Marcus. Vizualnaya dominanta v Rossii XVIII veka. Moskva: Novoe literaturnoe obozreniye, 2015.

Russkiy biograficheskiy slovar, ed. A. A. Polovtsov. Vol. 11. Sankt-Petersburg: Izdano Imperatorskim Russkim Istoricheskim Obshchestvom, 1914: 92-93. http://www.hrono.ru/biograf/bio_n/naryshkin_la.html

Warda, Anna. ,Cykl Felicyjski” w poezji rosyjskiej końca XVIII-początku XIX w. Łódź: Wydawnictwo PRIMUM VERBUM, 2013.

Warda, Anna. Obraz władcy w świetle rosyjskich osiemnastowiecznych dedykacji. In: Panegiryk jako element życia literackiego doby staropolskiej i oświeceniowej, ed. M. Sulejewicz-Nowicka, Z. Gruszka, Łódź: Wydawnictwo Uniwersytetu Łódzkiego, 2013: 229-237.

Warda, Anna. „O literaturnykh vzaimootnosheniyakh D. I. Khvostova i G. R. Derzhavina”. Acta Universitatis Lodziensis. Folia Litteraria Rossica. Zeszyt specjalny: Tradycja i inwencja w literaturach słowiańskich, ed. A. Warda, Łódź: Wydawnictwo Uniwersytetu Łódzkiego, 2015: 199-216. 